\title{
Characterization and Evaluation of Antibiotic Susceptibility Pattern of Coagulase Negative Staphylococci Isolated from Common Clinical Specimens in a Central Hospital in Delta State, Nigeria
}

\author{
JEMIKALAJAH, D J \\ Department of Microbiology, Delta State University, Abraka, Delta State Nigeria \\ Email: jemikalajahjohnson2007@yahoo.com
}

\begin{abstract}
The emergence of coagulase negative Stapylococci as major pathogens reflects the increased use of implants in hospitals. Fifty-four coagulase-negative staphylococci were isolated from a total of 242 clinical specimens at the Central Hospital, Kwale. All isolates were identified by standard bacteriological methods. Antibiotic sensitivity test was performed on all coagulase- negative staphylococci (CoNS) isolates using the modified Kirby-Bauer method with 10 different antibiotics. Staphylococcus epidermidis was the commonest species (83.3\%), while Staphylococcus saprophyticus was $16.7 \%$, mainly from urine samples. Highest sensitivity was found with ofloxacin (81.5\%), followed by ciprofloxacin $(77.8 \%)$ and, highest resistance occurred with cotrimoxazole to which no isolate was sensitive.
\end{abstract}

\section{DOI: https://dx.doi.org/10.4314/jasem.v23i1.27}

Copyright: Copyright (c) 2019 Jemikalajah. This is an open access article distributed under the Creative Commons Attribution License (CCL), which permits unrestricted use, distribution, and reproduction in any medium, provided the original work is properly cited.

Dates: Received: 19 December 2018; Revised: 22 January 2019; Accepted 31 January 2019

Keywords: Characterization, Antibiotics, Coagulase- negative -Staphylococci

Coagulase-negative Staphylococci (CoNS) are morphologically similar to Staphylococcus aureus. They are Gram-positive, non-spurring, non-motile cocci. Colonies are usually non-pigmented (Humphreys, 2002). They are found among the normal flora of human skin and mucous membranes. They have been long regarded as harmless skin commensals and dismissed as culture contaminants. Previously, their potentially important role as pathogens and their increasing incidence have been recognised (Kloos and Bannerman, 1994; Von Eiff et al., 1998).The emergence of CoNS as major pathogens reflects the increased use of implants such as cerebrospinal shunts, intravascular lines and cannulae, cardiac valves, pace-makers, artificial joints, vascular grafts and urinary catheters, and the increasing number of severely debilitated patients in hospitals (Humphreys, 2002). Staphylococcus epidermidis accounts for about $75 \%$ of all clinical isolates, and together with other novobiocinsusceptible CoNS, has emerged as a major cause of nosocomial infections, particularly, in bacteremia (Von Eiff et al., 2001). Stphylococcus haemolyticus is ranked second after Stphylococcus epidermidis and has been associated with septicaemia in new-borns and various infections in persons with compromised host defences and implanted foreign bodies (Shittu and Kolawole, 2005). Staphylococcus saprophyticus is an important cause of urinary tract infections in young, sexually active men and women (Von Eiff et al., 2001). Other species include Staphylococcus hominis, Staphylococcus schleiferi, Staphylococcus capitis and Staphylococcus lugdunensis, amongst others (Leven et al., 1995). Previous reports have indicated that Staphylococcus epidermidis has caused some cases of osteomyelitis, wound infection, otitis media, endophthalmitis, urinary tract infection and even meningitis and pneumonia, but this has not been proven (Peters et al., 1995; Heilmann and Peters, 2000).Multiple antibiotic resistances, in particular, methicillin resistance, is frequent among CoNS hospital strains on a global scale (Jarlov, 1999). The resistance genes found in multiple resistant CoNS are the same as those in Stapyylococcus aureus (Archer and Climo, 1994).

This study is to characterize and evaluate the antibiotic susceptibility pattern of CoNS in common clinical specimens in a General Hospital Delta State, Nigeria.

\section{MATERIALS AND METHODS}

Study area: This study was carried out in a Central Hospital Delta State, Nigeria from May to October 2018. Kwale has a population of 114,1171 people, located in the South-South geopolitical zone of Nigeria. It is a semi-urban town with the major 
occupation of farming, trading, civil servants and students (World Gazetter, 2007).

Sample collection: A total of two hundred and fortytwo (242) samples which include conjunctival swabs; 62, blood samples; 50, wound swabs/biopsies; 47, urine; 56, and ear swabs; 27 were collected from patients by random sampling technique at the Medical Laboratory Department of the Central Hospital Kwale. All Samples were analysed immediately after collection.

Preparation of media: All media used (nutrient agar, MacConkey agar, blood agar, Glucose broth and Sodium thioglycolate broth) were weighed appropriately and prepared according to manufacturers instruction. They were autoclaved at $121^{\circ} \mathrm{C}$ for $15 \mathrm{~min}$ and allowed to cool before use (Cheesbrough, 2000).

Isolation of bacteria: Specimens were inoculated on blood agar, MacConkey agar, and chocolate agar with the exception of blood samples. The blood samples were first inoculated in Brain heart infusion broth and Sodium thioglycolate broth and incubated at $37^{\circ} \mathrm{C}$ for 10 days. Signs of growth, turbidity, haemolysis, and bubbles were checked for within this period before being sub-cultured into the abovenamed plates. The plates were incubated at $37^{\circ} \mathrm{C}$ for 24hours.
Identification of bacterial isolates: All the CoNS isolates were identified using the bacteriological techniques and parameters, which include the biochemical characteristics, morphological, and cultural appearance as described by Cheesbrough (2000).

Antibiotic sensitivity pattern of CoNS: Antibiotic sensitivity test was carried out using the modified Kirby-Bauer disc diffusion method as described by Cheesbrough (2000).

Ethical permission: Ethical permission/approval was obtained from the ethical committee of Central Hospital Kwale.

\section{RESULTS AND DISCUSSION}

Out of the 54 CoNS isolates obtained from this study, Staphylococcus epidermidis was the commonest species $(83.3 \%)$, followed by Staphylococcus saprophyticus (16.7\%). This is similar to the findings of Mohan et al (2002) who in their study of CoNS reported Staphylococcus epidermidis as the most common species (82.3\%), followed by Staphylococcus saprophyitcus (15.6\%); and of Monsen et al (2005), who recorded that all CoNS isolates were Staphylococcus epidermidis except one (Table 1).

Table1: Distribution of 54 CoNS isolates in clinical specimens

\begin{tabular}{lllll}
\hline Body site & \multicolumn{2}{c}{$\begin{array}{l}\text { S. epidermidis } \\
\text { Number }\end{array}$} & Percentage & \multicolumn{2}{c}{ S. saprophyticus } \\
& Number & Percentage \\
\hline Conjunctival & 14 & 25.9 & 2 & 3.7 \\
Blood & 14 & 25.9 & - & - \\
Wound swab/biopsy & 12 & 22.2 & 1 & 1.9 \\
Urine & 2 & 3.7 & 6 & 11.1 \\
Ear swab/discharge & 3 & 5.6 & - & - \\
Total isolates & 45 & 83.3 & 9 & 16.7 \\
& & & & \\
\hline
\end{tabular}

However, this result does not agree with that of Monsen et al (2005), who reported that all species isolated were Staphylococcus epidermidis except only one species of Staphylococcus haemolyticus; also Shittu and Kolawole (2005) observed that Staphylococcus haemolyticus ranked second after Staphylococcus epidermidis (Table 2). The highest frequency of $11.1 \%$ was observed in urine samples for Staphylococcus saprophyticus. This agrees with the work of Mohan et al (2002) who reported that Staphylocccus saprophyticus strains were isolated mainly from urine; but disagreed with the findings of Uesugi et al (1996) who reported Staphylocccus epidermidis as more prevalent (36.0\%) than Staphylocccus saprophyticus $(26.0 \%)$ in urine samples. This indicates that Staphylocccus saprophyticusis becoming more common in urine samples than in other clinical specimens. This further implies that the clinical importance of CoNS in clinical specimens including urine cannot be overemphasized. Resistance to contrimoxazole was $100 \%$. The report of Zakaria (2005), however, showed a resistance of $63.1 \%$ to contrimoxazole tested on CoNS isolates in Palestine as shown on the comparative disc sensitivity (Table 2).All the strains of CoNs were resistant to one or more of the 10 antibiotics used for the study. Highest sensitivity was observed in ofloxacin $(81.5 \%)$, followed by ciprofloxacine (77.8\%), both of which fluoroquinolones and lowest sensitivity occurred in tetracycline (20.4\%). No isolate was sensitive to cotrimoxazole (Table 3). 
Table 2a: Disc sensitivity pattern of CoNS isolates

\begin{tabular}{llllllllll}
\hline Number of strain & & OFL & & CIP & & AUG & \multicolumn{3}{c}{ AMX } \\
\hline $\mathrm{N}$ & $\mathrm{S}$ & $\mathrm{R}$ & $\mathrm{S}$ & $\mathrm{R}$ & $\mathrm{S}$ & $\mathrm{R}$ & $\mathrm{S}$ & $\mathrm{R}$ & $\mathrm{S}$ \\
& 38 & 7 & 38 & 7 & 35 & 10 & 29 & 16 & 61 \\
S. epidermidis & & & & & - & & & & \\
$\mathrm{N}=45$ & & & & & & & & & \\
& $(84)$ & $(16)$ & $(84)$ & $(16)$ & $(78)$ & $(22)$ & $(64)$ & $(36)$ & $(64)$ \\
& 6 & 3 & 4 & 5 & 6 & 3 & 4 & 5 & 4 \\
S. saprohyticus & $(67)$ & $(33)$ & $(44)$ & $(56)$ & $(67)$ & $(33)$ & $(44)$ & $(56)$ & $(44)$ \\
$\mathrm{N}=9$ & & & & & & & & & \\
\hline
\end{tabular}

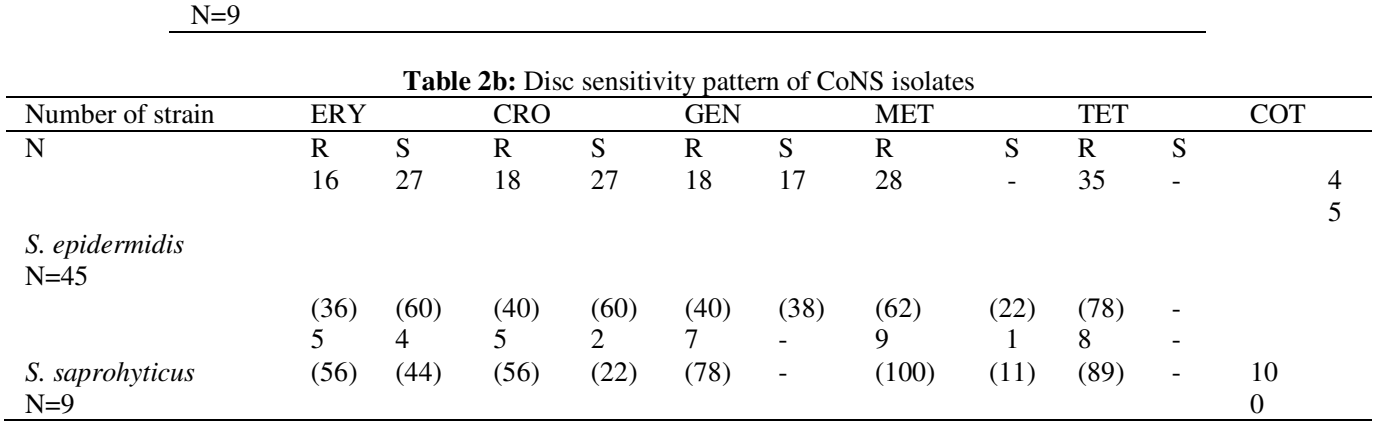

$L=$ Percentage of number $; \quad O F L=O f l o x a c i n ; \quad E R Y=$ Erythromycin; N=Number of strains; $C I P=$ Ciprofloxacin; GEN=Gentamicin; $S=$ Sensitivity $; \quad C R O=$ Ceftriaxone $; \quad T E T=$ Tetracycline $; \quad R=$ Resistance $; \quad A U G=$ Augmentin $; \quad C O T=$ Cotimoxazole $; \quad A M X=A m o x y c i l l i n ;$ MET=Methicillin

This is similar to the report of Manikandan et al (2005) who recorded $60 \%$ sensitivity of CoNS isolates to ciprofloxacin, although, it reflects an increased sensitivity. This study was done in India, the difference in geographical area may be responsible for the seemingly higher sensitivity. Olayinka et al (2005) reported antibiotic resistance of $16.1 \%$ to ciprofloxacin, which is relatively lower than $22.2 \%$ resistance obtained in this study. This indicates an increase resistance. Also, the result of this study does not agree with that of Obi et al (1996) who found that all CoNS isolates were sensitive to ofloxacin; and of Shobha et al (2005) who reported $100 \%$ sensitivity to ciprofloxacin in a study of CoNS in India. This antibiotic sensitivity pattern may imply that CoNS isolates are becoming increasingly resistant to fluoroquinolones which may be due to uncontrolled use of antibiotics and, the resistance patterns of CoNS which may vary from one geographical area to another.

Resistance of methicillin was $68.5 \%$, being the third highest resistance, after contrimoxazole and tetracycline. This is relatively high when compared with the result of Mohan et al (2000) which showed more than $20 \%$ resistance to methicillin, and with that of Olayinka et al (2005) who reported that resistance pattern of CoNS to methicillin was $49.1 \%$ when studying CoNS in Zaria, Nigeria. This reflects an increasing resistance to methicillin and may correlate with increased indiscriminate use of antibiotic in hospitals, and increased cross-reflection with hospital-acquired CoNS strains.
Table3: Antibiotic sensitivity pattern of CoNS strains

\begin{tabular}{llll}
\hline Antibiotic & $\begin{array}{l}\text { number of } \\
\text { strains }\end{array}$ & $\begin{array}{l}\text { \% sensitive } \\
\text { strains }\end{array}$ & $\begin{array}{l}\% \text { resistant } \\
\text { strains }\end{array}$ \\
\hline Ofloxacin & 44 & 81.5 & 18.5 \\
Ciprofloxacin & 42 & 77.8 & 22.2 \\
Augmentin & 41 & 75.9 & 24.1 \\
Amoxicillin & 36 & 66.7 & 33.1 \\
Erythromycin & 33 & 61.1 & 38.9 \\
Ceftriaxone & 31 & 57.4 & 42.6 \\
Gentamicin & 28 & 51.9 & 48.1 \\
Methicillin & 17 & 31.5 & 68.5 \\
Tetracycline & 11 & 20.4 & 79.6 \\
Cotrimoxazole & - & - & 100.0 \\
\hline
\end{tabular}

Conclusion: Staphylococcus epidermidis is the commonest CoNS species obtained from clinical specimens, followed by Staphylococcus saprophyticus, which appears to be prevalent in urine samples. This study has shown that fluoroquinolones such as ofloxacin and ciprofloxacin appear to be the most potent antibiotics against CoNS strains.

Acknowledgement: We highly appreciate our volunteers who agreed to take part in this study and the management and staffers of Central Hospital, Kwale, Delta State, Nigeria.

\section{REFERENCES}

Archer, GL; Climo, MW (1994). Antimicrobial susceptibility of coagulase-negative staphylococci. Antimicrobial agents and Chemother, 38:2231-7.

Cheesbrough, M (2000). Biomedical tests to identify bacterial. In: District Laboratory Practice in 
Tropical Countries. Part 2. United Kingdom: Cambridge University Press. P. 132-143.

Heilmann, C (2000). Biology and Pathogenicity of Staphylococcus epidermidis. In: Fischetti, VA; Novick, RP; Ferretti, JJ (eds). Gram-positive pathogens. Washington DC: ASM: P. 442-9.

Humphreys, H(2002). Staphylococcus. In: Greenwood, D; Slack, RCB; Peutherer, JF (eds). Medical Microbiology. A guide to microbial infections: Pathogenesis, Immunity, Laboratory diagnosis and control, $16^{\text {th }}$ ed. London: Churchill Livingstone. P. 168-173.

Jarlov, JO (1999). Phenotypic characteristics of coagulase-negative staphylococci: typing and antibiotic susceptibility. All Purpose Medical Information System suppl; 91:1-42.

Kloos, WE; Bannerman, TL (1994). Update on Clinical Significance of

Leven, M; Verhoeven, J; Pattyn, SR (1995). Rapid and economical method for species identification of clinically significant coagulase-negative staphylococci. J. Clinical Microbiol. 33(5): 1060-1063.

Manikandan, P; Bhaskar, M; Revathy, R; John, RK; Narendran, V (2005). Speciation of coagulasenegative staphylococci causing bacterial keratitis. Indian J. Opthalmology; 53:59-60.

Mohan, U; Jindal, N; Aggarwa, P (2002). Species distribution and antibiotics sensitivity pattern of coagulase-negative staphylococci isolated from clinical specimens. Indian J. Med. Microbiol. 20:45.

Monsen, T; Karisson, C; Wistrom, J (2005). Spread of clones of multidrug-resistant coagulasenegative Staphylococci within a University hospital. Infection Control of HospitalEpidemiolology; 26(1): 76-80

Obi, CL; Iyiegbuniwe, AE; Olukoya, DK; Babalola, C; Igumbor, EO; Okonta, AA (1996). Antibiograms and plasmids of Staphylococcus aiureus and coagulase-negative Staphylococci isolated from differeentclinical sources. Cent. Afr. J. Med; 42(9): 158-61

Olayinka, BO; Olayinka, AT; Onaolapo, JA (2005). Pattern of resistance to vancomycin and antimicrobial agents in Staphylococcal isolates in a University Teaching Hospital. African $J$. Clinic. Expr. Microbiolol. 6(1):21-27.

Peters, G; Von Eiff, C; Hermann, M (1995). The changing pattern of coagulase-negative staphylococcus as infectious pathogens. Current Opinion Infection Disease; 8 (sppl 1): 12-9.

Shittu, AO; Kolawale, DO (2005). The discovery of a multi-resistant Staphylococcus haemolyticus clone in the hospital and community environment in South Western Nigeria. Ostomy Wound Management; 51(1): 67-70

Shobha, K L; Roa, PS; Thomas, J (2005): Survey of Staphylococcal isolates among hospital Personnel, environment and their antibiogram with special emphasis on methicillin resistance. Indian J. Med. Microbiol. 23(3): 186-188

Uesugi, A; Oguri, T; Igari J (1996). Antimicrobial susceptibility of coagulase-negative staphylococcus isolates from urine. $J$. Japanese Assoc. Infectious Diseases; 70(2): 187-97

Von Effi, C; Heilmann, C; Peters, G (1994).Staphylococcus epidermidis: Why is it so successful? Clinical Microbiology Infection; 4(6): 297-300.

World Gazetter, (2007). Nigeria: largest cities and towns and statistics of their population: http://worldgazetteer.com

Zakaria E.A. (2005): Increasing ciprofloxacin resistance among prevalent urinary tract bacterial isolates in Gaza Strip, Palestine. $J$. Biomed. Biotechnol. 3:238-241. 